\section{PS-098-1 胸壁滑膜肉喱の一何}

\section{独立行政法人国立病院機構兵庫中央病院呼吸器外科}

橋本 章太郎, 宮本 良文

症例は 55 歳男性. 2000 年 8 月ごろより咳濑, 学作時呼吸困難が出現し, 大量

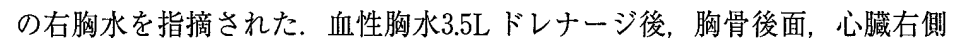
に約 $4 \mathrm{~cm}$ の腫瘤を認め, 胸水細胞診抢よび培養は陰性, 胸水ヒアルロン酸 $206 \mu \mathrm{g} / \mathrm{ml}$, ADA 40.4IU/L であった. Solitary fibrous tumor や肉腫などを 疑い，2000年9月21日摘出術を施行した．腫崵は胸壁より発生しており，や や凹凸不整，黄白色充実性で，腫瘍周囲約 $5 \mathrm{~cm}$ の範囲の壁側胸膜や縱隔脂 肪組織とともに摘出した，摘出した腫堭は $55 \times 36 \times 35 \mathrm{~mm}$ ，厚い線維性被膜 に被われ，割面では壊死や出血が認められた，病理組織学的に，腫瘍細胞は 主にやや丸みのある核を有する小型で均一の紡錐形細胞がシート状もしくは 束状に配列し，一部ではやや多角状の細胞が增生してその中に腺管様構造も 存在し，二相性の性格が恐められた，免疫染色では, Vimentin (+), Cytokeratin $(+), \operatorname{EMA}(+), b c l-2( \pm), \operatorname{CEA}(-), \operatorname{S100}(-), a \alpha-\operatorname{SMA}(-)$ で，上皮梯成分では, Calretinin $(+), \operatorname{HBME}-1( \pm)$ であり, 滑膜肉腫と診断 された．壁側胸膜内に microscopic な転移巣を認めたが，術後6年を経過し た現在，再発の㠍候を認めず健在である．胸壁の滑膜肉腫は稀な疾患であり， 若干の文献的考察を加えて報告する。

\section{PS-098-3}

肺癌術後経過中にFDG-PETにて発見された胸壁 Hibernoma の1例

\section{石川県立中央病院呼吸器外科}

清水 陽介, 常塚 宣男, 田中 伸佳

【症例】56歳女性. 6 ケ月前に肺癌にて左上葉切除術施行（腺癌, pT2N0M0） follow up study として, F-18 fluolodeoxyglucose (FDG) -positron emission tomography（PET）を施行したところ, Standardized Uptake Value : SUV $\max =8.96$ で，右胸壁に集積を認めた，胸部 CTにて $4.0 \times 4.0 \times 2.0 \mathrm{~cm}$ の lower density area が認められた. MRI での T1およびT2-強調画像は骨格 筋と脂肪の中間域であった. dynamic MR (gadolinium- diethylenetriaminep entaacetic acid (Gd-DTPA) での peak enhancement は投与後2分であった. 手術にて主要切除術を施行した. 腫瘍は広背筋と前鈮筋との間に存在し5.8 $\times 4.2 \times 2.8 \mathrm{~cm}$ の被包化された腫瘍であった. 病理学的に Hibernoma と診断 された.【考察】Hibernomaは brown fat 起源の腫瘍であり, 1906年に Merkei らが最初に報告した稀な腫瘍である．世界で約170例の報告がある稀 な腫瘍であり，文献的考察を含め報告する.

\section{PS-098-2 第一肋骨に発生した巨大骨巨䊼胞腫の一切除例}

松村 勇輝 ${ }^{1}$, 塩野 知志 ${ }^{1}$, 加藤 博久 ${ }^{1}$, 佐藤 徹 ${ }^{1}$, 金内 直樹 ${ }^{2}$

骨巨絸胞腫の一般的な好発部位は長管骨の骨端部で, 肋骨原発は極めて稀で ある．今回我々は第一肋骨を原発とし，50年の経過を経た骨巨細胞腫の一切 除例を経験したので考察も含めて報告する，症例は 72 才女性，50年前に胸部 $\mathrm{X}$ 線にて左肺尖部の異常影を指摘されたが，当時は手術の危険が高いとされ 経過観察となった．その後は検診ごとに指摘されるが放置していた．本年2 月頃から左頸部・背部痛と左鎖骨上の腫瘤が増大してきたため当院に紹介さ れた．胸部造影 CT では左第一肋骨を主座とし，不均一に造影される直径約 $9 \mathrm{~cm}$ の腫瘍を認めた. 左の鎖骨下静脈は圧排されて造影されなかった. MRI では腫瘍内部に液面形成を示す多数の脘が認められた，生検を施行し， 動脈瘤性骨囊腫様の変化を伴う骨巨細胞腫と診断された，術中の出血予防と して術前に腫瘍栄養動脈の塞栓術を行った，手術では前方アプローチとして transmanubrial approach（以下 TMA）を施行したが，後壁との癒着が著し かったため後方アプローチとして後側方切開を追加した．腫瘍と周囲組織の 癒着は強かったが，血管系への浸潤は認めず，胸壁，第一・第二肋骨の一部 を含めた腫瘍摘出を行うことができた，術後経過は TMA 切開部の創痛の管 理に難渋し，左腕の挙上制限が退院まで残ったが，術後1ヶ月で元気に退院 となった．腫瘍の大きさは $9.5 \times 6.5 \times 8.0 \mathrm{~cm}$ で病理組織所見では第一肋骨を 原発とし，骨巨細胞腫の特徵である増殖する間質細胞と多核巨細胞を有して いた．腫瘍内に動脈瘤性骨囊腫様の変化も多数認められた。

\section{PS-098-4 乳癌手術後20年目に発症した胸壁転移の1切除例}

\author{
岡山済生会総合病院外科
}

片岡 正文, 大原 利憲, 河本 洋伸

【はじめに】乳癌手術後の再発, 転移は5年, 10 年以降に発症することも稀で はなく，長期の経過観察が必要である，今回我々は，乳癌切除後 20 年目に胸 壁に再発し切除した1例を経験したので報告する.【症例】症例は，69歳女性. 20 年前に左乳癌にて左乳房切断術を行った，近医で経過観察中左前胸壁に腫 瘤が出現し次第に増大するため当院に紹介となった，左前胸壁に突出する $3.5 \mathrm{~cm}$ 大の腫瘤を認めた. CT では胸骨に接し第 3 ，4胁軟骨を取り囲むよう に強く造影される腫瘤を認め, 転移性胸壁腫瘍が疑われた。CTガイド下針 生検にて腺癌を認め全身検索にて他に病巣を認めなかったため手術を行った. 手術は腫瘍辺縁より約 $2 \mathrm{~cm}$ に円形の皮切をおき胸骨左側部の一部，第 2,3 , 4肋軟骨, 内胸動静脈を一塊として切除した。 久損部は, Gore Texにて補 強した後右腹直筋皮弁にて再建した，手術標本の病理所見では，胸壁皮下脂 肪内に肋軟骨を取り囲むように乳癌の転移病巣を認めた。術後経過は良好で 現在アロマターゼ阻害剂を内服し外来経過観察中である.【まとめ】乳癌手術 20 年後の再発例は稀と考えられるので報告した. 